\title{
$\mathrm{WC}-12$ 22wt\%Co 초경합금에서 미세조직 인자가 인장 성질에 미치는 영향 류성현 ${ }^{1,2}$ · 김경일 ${ }^{1}$ - 노우람 ${ }^{1} \cdot$ 김상섭 $^{2}$ · 조규섭 ${ }^{1, *}$ \\ 1한국생산기술연구원 뿌리기술연구소 \\ 2인하대학교 신소재공학과
}

\section{Effect of Microstructural Parameters on the Tensile Property of WC-12 22wt\%Co Cemented Carbide}

\author{
Seong Hyeon Ryu ${ }^{1,2}$, Kyung Il Kim¹, Wooram Noh', Sang Sub Kim², and Gue Serb Cho ${ }^{1}$,* \\ ${ }^{1}$ Research Institute of Advanced Manufacturing Technology, Korea Institute of Industrial Technology, \\ Incheon 21999, Republic of Korea \\ ${ }^{2}$ Department of Materials Science and Engineering, Inha University, Incheon 22212, Republic of Korea
}

\begin{abstract}
Cemented carbide is a kind of composite material in which fine particles of carbide are embedded into the matrix of a binder metal. It has a long service life because of its superior mechanical properties. In this study, the overall tensile behavior of a cemented carbide, WC-Co, was investigated by considering its characteristic microstructure parameters. Tensile strength and strain to fracture were evaluated by measuring the stress-strain curves of a standard tensile specimen. Scanning Electron Microscopy (SEM) was used to analyze both the average size and contiguity of WC carbide particles, as well as the mean free path of the Co (cobalt) binder. Specific correlations between mechanical and microstructural features were examined and elucidated for various volume fractions of the binder metal. The Co content and the mean free path of the Co binder were in a proportional relationship, and tensile strength showed an opposite tendency to Co content. Regarding Young's modulus and strain, it was confirmed that a large difference appears depending on the crystal structure of the Co phase. Furthermore, by probing topology of the fractured surface of the tensile specimen it was determined that the existence of irregular voids could contribute to the statistical variance in the measured values.
\end{abstract}

(Received December 28, 2020; Accepted January 28, 2021)

Keywords: WC-Co cemented carbide, tensile strength, elongation, microstructure, correlation analysis

\section{1. 서 론}

자동차 부품용 휠 너트는 냉간 단조를 통해서 만들어지고 있고, 이러한 휠 너트의 형상을 냉간에서 단조하기 위한 금 형 소재 요구 조건은 높은 경도와 인성을 가지고 있어야 한 다. 현재는 고경도의 WC 탄화물을 인성이 있는 금속 결합 제를 복합화한 초경 소재들이 금형으로 많이 사용되고 있으 며, 그 중에 WC-Co합금이 오랫동안 사용되어 왔다.

$\mathrm{WC}-\mathrm{Co}$ 초경합금에서 $\mathrm{WC}$ 의 경우 압축강도는 대략

- 류성현: 석사과정, 김경일·노우람·조규섭: 연구원, 김상섭: 교수

*Corresponding Author: Gue Serb Cho

[Tel: +82-32-850-0445, E-mail: ]gscho@kitech.re.kr

Copyright (C) The Korean Institute of Metals and Materials
$2.7 \mathrm{GPa}$ 로 매우 높지만, 인장강도의 경우 $344 \mathrm{MPa}$ 로 압축 강도에 비해서 상당히 낮은 편이다. 즉 압축응력보다 인장 응력에 매우 취약하며, 금형의 수명은 반복되는 인장 응력 에 의해 피로 파괴가 일어날 것이다. 자동차용 휠 너트의 경우 다단 냉간 단조기(cold forming machine)에서 주로 제조되며, 단조 하중이 전달되는 금형의 특정한 위치가 높 은 인장 응력을 반복적으로 받게 되면서 균열이 발생하고 파괴에 이르게 된다 $[1,2]$. 본 연구에서는 냉간 단조용 초 경 금형의 피로 수명을 예측과 수명 향상을 위한 기초 연 구의 전 단계로서 휠 너트 단조에 사용되는 WC-Co 초경 합금의 미세조직 인자들과 그에 따른 기계적인 성질, 특히 인장파괴강도, 탄성계수 등의 인장 물성값의 상관관계를 규 명하고자 하였다. 
WC-Co 초경합금의 기계적 물성값을 결정하는 미세구조 적 인자는 $\mathrm{WC}$ 입자 크기와 결합제로 쓰이는 코발트 $(\mathrm{Co})$ 층의 두께이다 [3]. 현재 단조용 금형으로 사용되는 WC$\mathrm{Co}$ 초경합금의 $\mathrm{WC}$ 입자 크기는 $0.5 \sim 10 \mathrm{um}$ 범위이며, $\mathrm{WC}$ 입자 크기가 작을수록 굽힘 파단강도 및 경도와 같은 기계적 성질이 높다고 알려져 있다 [4,5]. 그리고 $\mathrm{Co}$ 층의 두께는 $\mathrm{Co}$ 의 평균 자유행정거리(binder mean free path, $\lambda_{\mathrm{Co}}$ )를 말하며, $\mathrm{Co}$ 함량에 비례한다 [6]. 일반적으로 $\mathrm{Co}$ 층 의 두께가 얇을수록 기계적 성질이 증가하며, $\mathrm{Co}$ 층의 두 께를 줄이는 방법으로는 $\mathrm{Co}$ 함량을 낮추거나, WC 입자 크기를 미세하게 하고, 균일하게 분산시키는 것이 중요하 다. 하지만 $\mathrm{Co}$ 층의 두께를 줄이기 위해 정해진 범위 이상 으로 $\mathrm{Co}$ 함량을 줄이면 $\mathrm{Co}$ 기지재가 강화재를 감싸는 역 할을 못하게 되고, 이는 인성의 저하로 이어진다.

현재 WC-Co 초경합금의 경도와 파괴 인성 등에 대한 연 구는 많이 진행되었으나[3,7-10], 인장 시험에 대한 연구 결 과 및 보고는 매우 부족하다. 이전의 연구들에서는 WC-Co 초경합금의 인장 강도를 유추하기 위해 3점 굽힘 시험에서 얻어지는 횡 파단 강도(transverse rupture strength, TRS)를 인장 강도로 변환하여 사용하는 방법[11]과 시편의 양 그립 부를 변형하여 나사산을 형성하거나, T-자 형상으로 만들어 인장 시험하는 방법 등이 시도되었다 [12,13]. 하지만 굽힘 강도를 인장 강도로 변환하는 방식은 재료 상수 $\mathrm{m}$ 에 대한 신뢰성이 부족하고, 시편 그립부를 변형하여 인장 시험을 하 는 경우 그립부에 응력 집중이 생겨 일축 응력-변형률 선도 (stress-strain curve) 해석에 어려움이 있었다.

이러한 문제를 해결하고 WC-Co 초경합금의 인장 강도 를 얻기 위해 본 연구에서는 표준규격에 적합한 크기와 모 양으로 정형 상태(net shape)의 인장 시편을 제작하고 1축 인장 시험으로 초경 합금의 인장 파괴강도와 탄성계수를 구하였다.

\section{2. 실험 방법}

본 연구에서는 냉간 단조용 초경 금형의 상용적인 제조 과정과 동일하게 인장 시험편을 제작하였으며, $\mathrm{Co}$ 의 무게분 율 $(\mathrm{wt} \%)$ 에 따른 $\mathrm{WC}-12 \mathrm{wt} \% \mathrm{Co}(12 \mathrm{Co}), \mathrm{WC}-20 \mathrm{wt} \% \mathrm{Co}$ $(20 \mathrm{Co}), \mathrm{WC}-22 \mathrm{wt} \% \mathrm{Co}(22 \mathrm{Co})$ 의 3 가지 조성의 미세구조적 인자들이 기계적 성질에 미치는 영향을 파악하고자 하였다.

본 실험에 사용된 초경합금의 함량 분석은 화학분석 (ICP-OES)을 통해 측정하였으며, $\mathrm{Co}$ 와 $\mathrm{C}$ 의 무게 분율을 측정한 후 $\mathrm{WC}$ 의 무게 분율 및 $\mathrm{WC}$ 와 $\mathrm{Co}$ 의 상대 부피 분율을 계산하였다. 초경합금의 미세조직 분석은 주사전자 현미경(scanning electron microscope, SEM, Quanta 200 FEG, TEI, Korea)을 이용하였으며, 인장 시험편의 그립 (grip)부를 절단 후 연마하여 시편으로 사용하였다. WC 입 자크기와 $\lambda_{\mathrm{Co}}$ 는 $\mathrm{SEM}$ 미세 조직 사진상에서 단선 분석 (linear intercept) 방법으로 측정하였다 [14].

WC-Co 초경합금에서 기계적 성질에 영향을 미치는 인 자 중 하나인 탄화물 접촉도(contiguity, $C$ )는 전체 상계면 중 Carbide-Carbide 접촉 계면의 분율을 말한다 [15]. 접 촉도의 범위는 0 에서 1 까지 이며, 일반적으로 $\mathrm{Co}$ 의 부피 분율에 반비례한다. 접촉도를 구하는 방법은 Gurland에 의 해 연구가 진행되었으며[15], 본 연구에서는 단선 분석에 서 측정한 계면 접촉 수를 아래의 식 1 에 대입하여 접촉 도를 구하였다.

$$
C=\frac{2 N_{W C} W C_{C}}{2 N_{W C_{-} W C}+N_{W C_{-} C o}}
$$

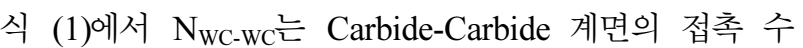

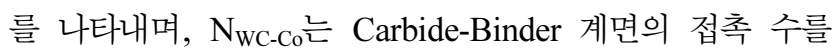
나타낸다. Carbide 계면은 서로를 공유하기 때문에 $\mathrm{N}_{\mathrm{wC}}$ wc앞에 2를 붙여준다.

WC-Co 초경합금의 상분석은 $\mathrm{X}$ 선 회절분석기(X-Ray diffractometer, X'Pert-Pro MPD/PANalytical)를 사용하였으 며, 사용된 $\mathrm{X}$-선은 $\mathrm{Cu} \mathrm{K \alpha} \alpha$ 선 $(\lambda=0.15456 \mathrm{~nm})$ 이었으며, $\mathrm{X}$-선 회절각 $(2 \theta)$ 의 주사 범위는 $20^{\circ} \sim 90^{\circ}$ 로 하였다. X-ray 회절에 나타나는 각 상의 peak들은 $\mathrm{WC}(101) \mathrm{d}=1.884 \AA$, FCC_Co (111) $d=2.047 \AA$, HCP_Co(101) $d=1.920 \AA$ 이었다.

그리고 기계적 물성은 경도와 인장 파괴강도값을 측정하 였다. 경도 시험은 로크웰 경도시험기(Mitutoyo, Wizhard) 를 이용하였고, 함량이 다른 $12 \mathrm{Co}, 20 \mathrm{Co}, 22 \mathrm{Co}$ 시편에 대하여 각각 다섯 번 측정하여 평균하였다. 인장강도 시험 은 만능 인장 시험기(MTS, Landmark $100 \mathrm{kN})$ 를 사용하 였으며, 시험 조건은 상온에서 크로스 헤드(cross head) 진 행속도 $3 \mathrm{~mm} / \mathrm{min}$ 으로 진행하였다. 시편은 KS B 0801 / $14 \mathrm{~A}$ 표준규격에 의거해서 제작하였으며, 제작된 인장 시편 은 아래의 그림 1 에 나타내었다. 인장 시험은 $\mathrm{Co}$ 함량에 따라 각각 다섯 개의 시편에 대하여 측정하였으며, 인장 시험 후 파단면을 주사전자현미경으로 관찰하였다.

\section{3. 결과 및 고찰}

화학 분석을 통해 WC-Co 초경합금의 성분 원소를 측정 하였으며, 그 결과를 표 1 에 나타내었다. 탄소 $(\mathrm{C})$ 의 무게 분율 $(\mathrm{wt} \%)$ 은 $12 \mathrm{Co}, 20 \mathrm{C}, 22 \mathrm{Co} 3$ 종 합금에 대하여 각각 


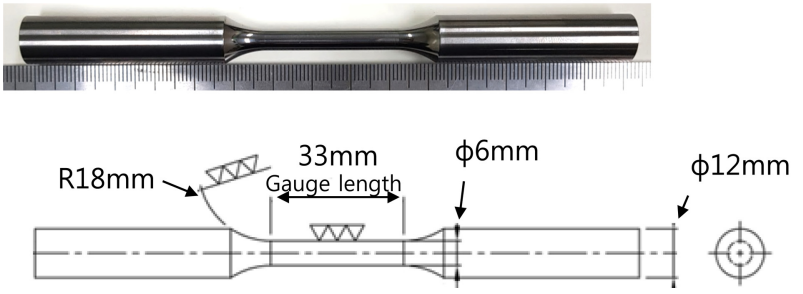

Fig. 1. Photograph and dimensions of WC-Co tensile test specimen.

Table 1. Chemical compositions(wt $\%$ ) and volume percent of WC-Co alloys.

\begin{tabular}{cccccc}
\hline Alloys & Co & C & W & V $_{\text {Co }}$ & $\mathrm{V}_{\text {WC }}$ \\
\hline WC-12Co & 12.0 & 5.36 & 82.64 & 19.3 & 80.7 \\
WC-20Co & 19.0 & 4.85 & 76.15 & 29.2 & 70.8 \\
WC-22Co & 20.3 & 4.68 & 75.02 & 30.9 & 69.1 \\
\hline
\end{tabular}

$5.36,4.85,4.68$ 로 나타났다. $\mathrm{Co}$ 의 무게 분율 $(\mathrm{wt} \%)$ 을 보 면 $12 \mathrm{Co}$ 시편의 경우 공칭 값과 같은 값이 나왔지만, $20 \mathrm{Co}$ 와 $22 \mathrm{Co}$ 의 무게 분율은 각각 19.0 과 20.3 로 공칭값 보다 작게 나타났다. $\mathrm{WC}$ 와 $\mathrm{Co}$ 각 상의 부피 분율은 $\mathrm{WC}$ 와 $\mathrm{Co}$ 의 밀도 $\left(\rho_{\mathrm{WC}}=15.63 \mathrm{~g} / \mathrm{cm}^{3}, \rho_{\mathrm{Co}}=8.90 \mathrm{~g} / \mathrm{cm}^{3}\right)$ 를 이용하였으며, 화학분석에서 얻어진 Co 함량값 $12.0,19.0$, $20.3 \mathrm{wt} \%$ 값을 대입하여 구하였다. $20 \mathrm{Co}$ 와 $22 \mathrm{Co}$ 는 매우 근접한 $\mathrm{Co}$ 함량과 $\mathrm{WC}$ 분율을 가지고 있는 것으로 나타 났다.

$12 \mathrm{Co}, 20 \mathrm{Co}, 22 \mathrm{Co} 3$ 종의 $\mathrm{WC}-\mathrm{Co}$ 초경 합금의 주사전 자현미경으로 관찰한 미세 조직 사진을 그림 2에 나타내 었다. 텅스텐 카바이드(WC) 입자는 밝은 회색이며, 이러한 카바이드를 결합하고 있는 코발트 $(\mathrm{Co})$ 는 검은 부분이다. 그 림 2의 (a)는 $12 \mathrm{Co}$ 조성의 미세조직 사진이며, $\mathrm{WC}$ 입자 크기는 매우 미세하며, $\mathrm{Co}$ 는 $\mathrm{WC}$ 사이에 매우 얇게 위치 하고 있다. 그림 2 의 (b)와 (c)는 $20 \mathrm{Co}$ 와 $22 \mathrm{Co}$ 조성의
Table 2. Microstructural characteristic values and hardness of the WC-Co alloys. (mean \pm standard deviation).

\begin{tabular}{|c|c|c|c|c|}
\hline Alloys & $\mathbf{d}_{\mathrm{WC}}(\mathrm{um})$ & $\lambda_{\text {Co }}($ um) & Contiguity & Hardness(HRa) \\
\hline $\mathrm{WC}-12 \mathrm{Co}$ & $0.80 \pm 0.46$ & $0.26 \pm 0.20$ & $0.45 \pm 0.12$ & $87.7 \pm 0.35$ \\
\hline WC-20Co & $2.43 \pm 1.26$ & $1.24 \pm 0.88$ & $0.39 \pm 0.12$ & $83.6 \pm 0.17$ \\
\hline WC-22Co & $2.39 \pm 1.34$ & $1.45 \pm 1.27$ & $0.35 \pm 0.14$ & $81.5 \pm 0.09$ \\
\hline
\end{tabular}

미세 조직 사진이다. 그림 2의 (b)와 (c)의 $\mathrm{WC}$ 입자는 (a)와 비교하였을 때 매우 조대한 입자인 것을 알 수 있다. $\mathrm{Co}$ 층의 분율은 $12 \mathrm{Co}$ 에서 가장 작게 나타나며, 그림 2 의 (b) $20 \mathrm{Co}$ 와 (c) $22 \mathrm{Co}$ 두 조성만을 비교하면 $22 \mathrm{Co}$ 가 좀 더 많은 분율이 있음을 알 수 있다. 초경합금의 경우 소결 과정에서 $\mathrm{WC}$ 입자는 삼각 프리즘의 형상을 가지게 되며 [16], $12 \mathrm{Co}, 20 \mathrm{Co}, 22 \mathrm{Co}$ 합금 모두 $\mathrm{WC}$ 입자가 각면을 가진 삼각 프리즘의 형태로 입자 성장한 것을 알 수 있다.

그림 2의 주사전자현미경 사진에서 얻어진 이미지(image) 에 대하여 각각의 WC-Co 초경 합금의 미세조직적 특성을 파악하였다. 이미지 분석은 단선 분석법을 이용하여 WC$\mathrm{Co}$ 초경 합금의 $\mathrm{WC}$ 입자 크기 $(\mathrm{dwc}), \lambda_{\mathrm{Co}}, \mathrm{WC}-\mathrm{WC}$ 접촉 도(contiguity)를 측정하였으며, 결과를 표 2에 나타내었다. 그립부 단면에서 측정한 로크웰 $\mathrm{A}$ 경도값도 같이 나타내 었다. 표 2 에서 $12 \mathrm{Co}$ 의 경우 $\mathrm{WC}$ 평균 입자 크기가 $0.80 \mathrm{um}$ 정도로 매우 미세한 것을 알 수 있으며, $2.43 \mathrm{um}$ 과 $2.39 \mathrm{um}$ 인 $20 \mathrm{Co}$ 와 $22 \mathrm{Co}$ 사이에는 큰 차이가 없는 것 으로 나타났다. 즉, $20 \mathrm{Co}$ 와 $22 \mathrm{Co}$ 에 사용된 $\mathrm{WC}$ 입자는 동일한 크기의 원료를 사용하여 동일한 수준의 소결 과정 을 거친 것으로 추정할 수 있다. $\mathrm{Co}$ 평균자유행로 $\lambda_{\mathrm{Co}}$ 의 경우 $\mathrm{Co}$ 함량이 증가할수록 $\lambda_{\mathrm{Co}}$ 는 증가하며, 반대로 $\mathrm{WC}-$ $\mathrm{WC}$ 접촉도는 감소하는 경향을 나타낸다. 이는 $\lambda_{\mathrm{Co}}$ 가 $\mathrm{Co}$ 함량에 비례하여 증가하며, 접촉도(contiguity)는 $\mathrm{Co}$ 함량에 반비례한다는 이전의 연구와 같은 결과를 나타낸다 [17].

그림 3,4 는 $\mathrm{WC}$ 입자 크기와 $\mathrm{Co}$ 의 평균자유행로 $\lambda_{\mathrm{Co}}$

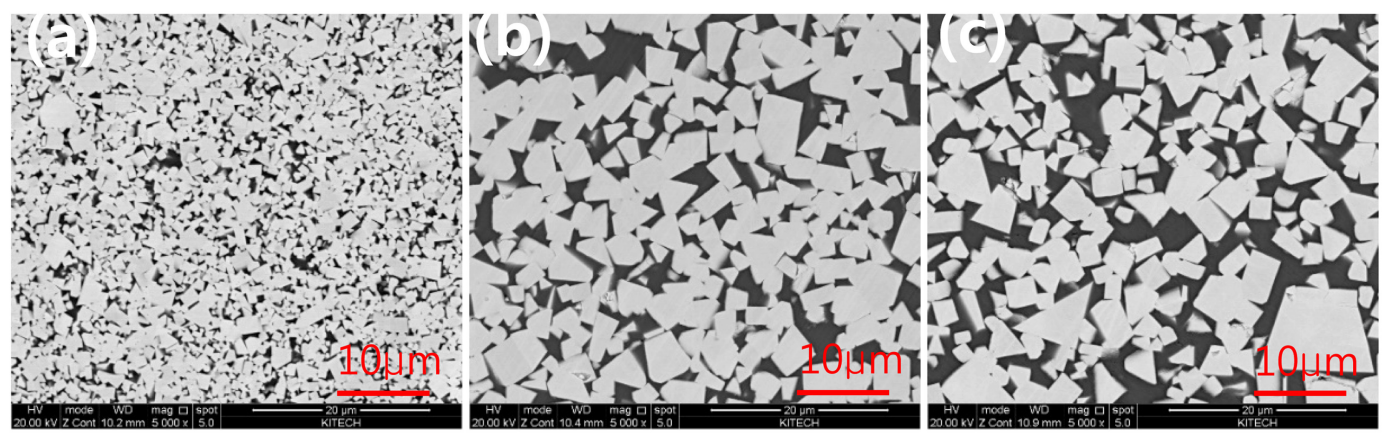

Fig. 2. SEM microstructures of the WC-Co alloys. (a) 12Co, (b) 20Co, (c) 22Co. 

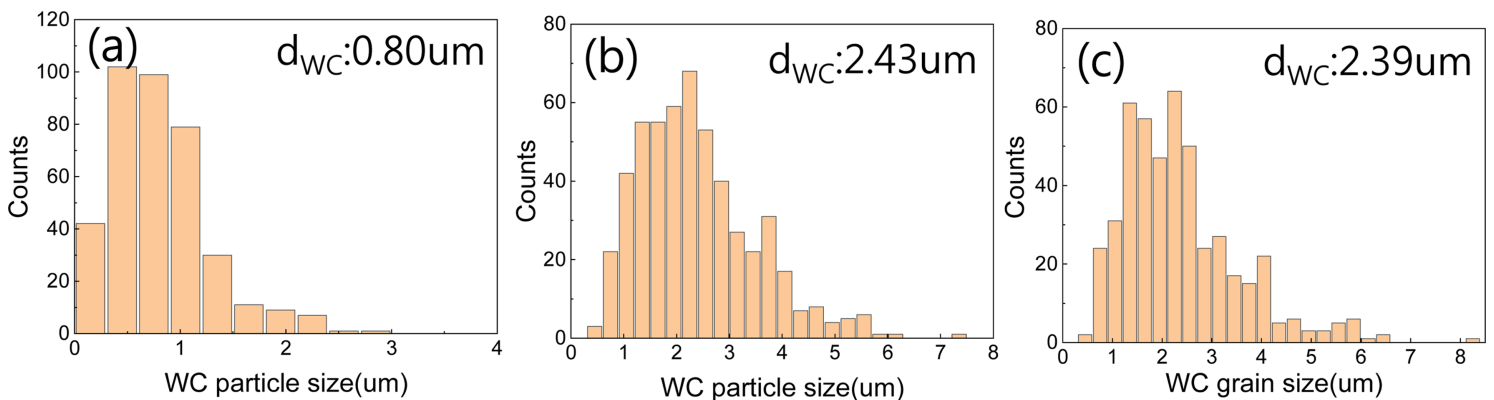

Fig. 3. Histograms of WC grain size in WC-Co alloys. (a) $12 \mathrm{Co}$, (b) 20Co, (c) $22 \mathrm{Co}$.
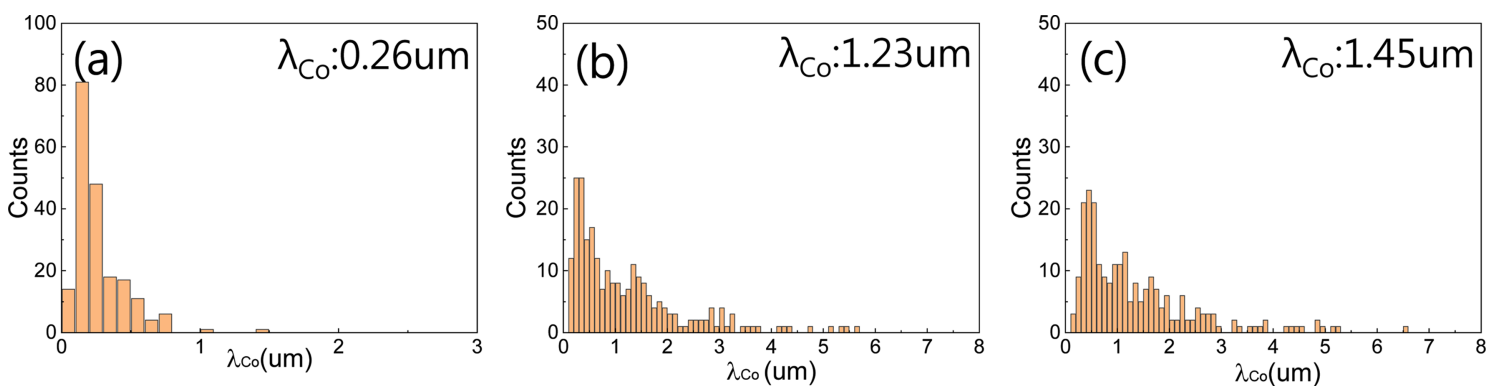

Fig. 4. Histograms of $\lambda_{\text {Co }}$ in WC-Co alloys. (a) $12 \mathrm{Co}$, (b) $20 \mathrm{Co}$, (c) $22 \mathrm{Co}$.

를 히스토그램으로 나타낸 것이다. $12 \mathrm{Co}$ 의 경우 $0 \sim 2.5 \mathrm{um}$ 크기 범위까지 나타났으며, $20 \mathrm{Co}$ 와 $22 \mathrm{Co}$ 의 경우 $0 \sim 6 \mathrm{um}$ 까지 넓은 범위에 분포하고 있다. $12 \mathrm{Co}$ 의 경우 상대적으 로 좁은 입자 분포를 나타내고 있으나, $20 \mathrm{Co}$ 와 $22 \mathrm{Co}$ 의 경우 약 2 um 크기에서 가장 많은 빈도수를 나타내고 있 지만, 그 이상의 크기도 비교적 많은 분포를 하고 있다. 특히, 7 8 um 크기의 매우 큰 $\mathrm{WC}$ 입자도 존재한다. 이러 한 조대한 $\mathrm{WC}$ 입자를 가지고 있는 초경 금형은 인장 성 질 값에 많은 편차를 나타낼 것으로 예측된다.

$\lambda_{\mathrm{Co}}$ 의 분포는 $12 \mathrm{Co}$ 의 경우 $0 \sim 1 \mathrm{um}$ 이며, $20 \mathrm{Co}$ 와 $22 \mathrm{Co}$

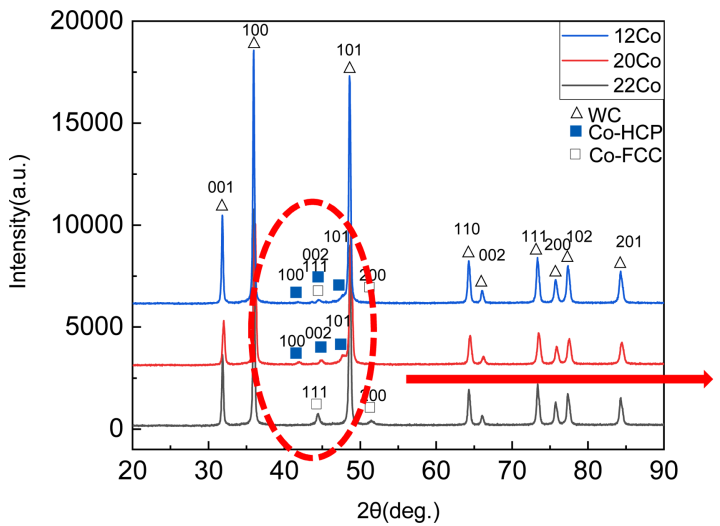

Fig. 5. X-ray diffraction patterns of WC-Co alloys.
는 0 5.5 um까지 나타났다. WC 입자 크기 분포와 동일하 게 코발트 결합제의 크기, 즉 $\mathrm{WC}$ 입자를 둘러싸고 있는 $\mathrm{Co}$ 층 두께도 넓게 분포하고 있다. $\mathrm{WC}$ 입자의 산포와 분 산 정도 차이에 따른 결과일 것으로 판단된다. 그러나 $20 \mathrm{Co}$ 와 $22 \mathrm{Co}$ 만을 비교하면 그림 2 의 조직사진에서 보이 는 것처럼 $22 \mathrm{Co}$ 가 좀 더 두꺼운 $\mathrm{Co}$ 층을 나타내고 있다. 이전의 연구에서 $\mathrm{WC}-\mathrm{Co}$ 초경 합금의 경도는 $\mathrm{WC}$ 입자 크기와 Co 함량에 영향을 받는다고 알려져 있으며[3-5], $\mathrm{Co}$ 함량이 가장 적고 $\mathrm{WC}$ 입자 크기가 가장 미세한 $12 \mathrm{Co}$ 의 경도 $(\mathrm{HRa})$ 는 $87.72 \pm 0.35$ 이고, $\mathrm{WC}$ 입자 크기가

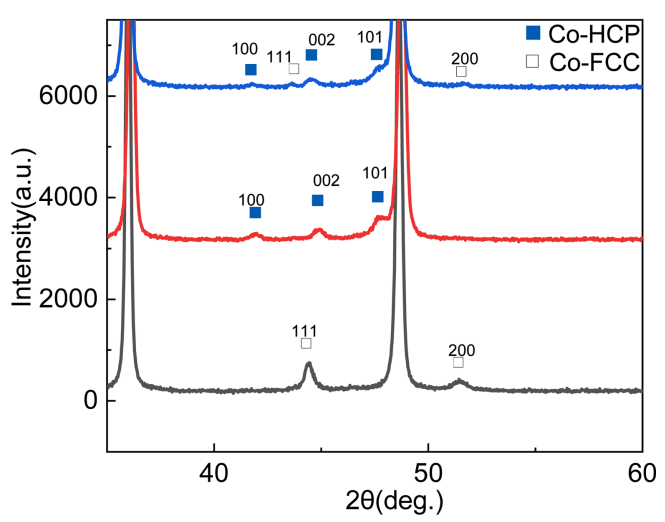



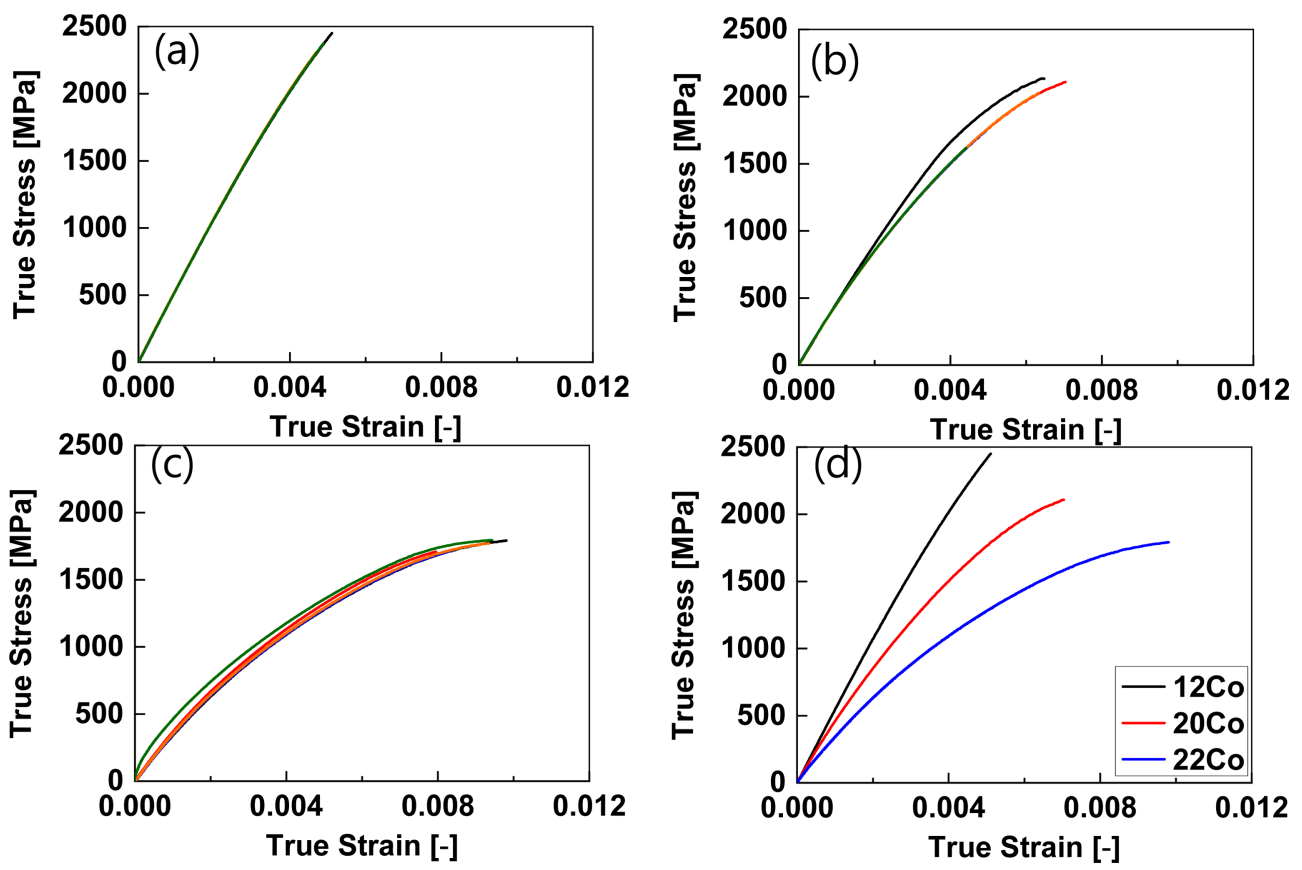

Fig. 6. Stress-Strain curve of WC-Co alloys. (a) 12Co, (b) 20Co, (c) 22Co, (d) compared between 12Co, 20Co and $22 \mathrm{Co}$.

서로 비슷한 $20 \mathrm{Co}$ 와 $22 \mathrm{Co}$ 를 비교하여 보았을 때, $20 \mathrm{Co}$ 는 $83.62 \pm 0.12,22 \mathrm{Co}$ 는 $81.50 \pm 0.09$ 로 $\mathrm{Co}$ 함량이 조금 증가함에 따라 경도가 조금 낮아짐을 알 수 있다.

그림 5 는 $12 \mathrm{Co}, 20 \mathrm{Co}, 22 \mathrm{Co}$ 초경합금 인장시편의 그 립부 단면에 대한 $\mathrm{X}$ 선 회절 패턴 결과이다. $\mathrm{X}$ 선 회절에서 $\mathrm{WC}$ 와 $\mathrm{Co}$ 상 피크만 관찰되었으며, 소결 중 액상 $\mathrm{Co}$ 와 반 응에 의해 생기는 $\mathrm{Co}_{\mathrm{x}} \mathrm{W}_{\mathrm{y}} \mathrm{C}$ 와 $\mathrm{W}_{2} \mathrm{C}$ 같은 탄화물은 관찰되 지 않고 있다. $\mathrm{Co}$ 는 $417^{\circ} \mathrm{C}$ 를 기준으로 고온 안정상인 $\mathrm{FCC}$ 구조와 저온 안정상인 $\mathrm{HCP}$ 로 두 영역으로 나누어 진다 [18]. $22 \mathrm{Co}$ 의 경우 $\mathrm{HCP}$ 상이 관찰되지 않고 모두 $\mathrm{FCC}$ 상만 관찰되며, $20 \mathrm{Co}$ 시편의 경우에는 $\mathrm{HCP}$ 상과 함께 $\mathrm{FCC}$ 상도 일부 관찰되었다. $12 \mathrm{Co}$ 의 경우 $\mathrm{HCP}$ 와 $\mathrm{FCC}$ 상 피크가 모두 관찰되었으나, $22 \mathrm{Co}$ 에 비하여 $\mathrm{Co} \mathrm{FCC}$ peak 가 많이 약한 것을 볼 수 있다. 결과적으로 금속 결합제인 $\mathrm{Co}$ 는 $12 \mathrm{Co}$ 와 $20 \mathrm{Co}$ 의 경우, 소결 과정 중에 $\mathrm{FCC}$ 상이 저 온상인 $\mathrm{HCP}$ 상으로 완전히 변태하지 못하고 일부 잔류하 는 것으로 나타났으며, $22 \mathrm{Co}$ 의 경우 고온상인 $\mathrm{FCC}$ 가 저
온상으로 전혀 변태되지 않고 있음을 알 수 있다.

각각의 초경합금에 대한 1 축 인장시험에서 얻은 인장 응 력-변형률 선도를 그림 6에 나타내었다. 초경 인장시편의 최종 파단은 모두 게이지(gauge) 부분에서 일어났다. $12 \mathrm{Co}, 20 \mathrm{Co}, 22 \mathrm{Co}$ 로 갈수록 그래프의 기울기가 줄어들고 파괴 강도 값이 낮아지는 경향을 나타내었다. 그림 6(a) $12 \mathrm{Co}$ 의 인장곡선은 선형성이 높고 일정한 값을 나타내고 있으며, 그림 6(b) $20 \mathrm{Co}$ 와 $6(\mathrm{c}) 22 \mathrm{Co}$ 의 경우 시험에서는 인장 파괴강도와 변형률의 편차가 많이 발생하고 있다. 이 러한 인장 파괴강도의 편차는 파면에서 관찰되는 결함에 의한 것으로 확인되었다.

$\mathrm{WC}-\mathrm{Co}$ 초경합금의 인장시험 곡선에서 $12 \mathrm{Co}$ 와 $20 \mathrm{Co}$ 의 경우 변형률이 매우 작아 $0.2 \%$ offset에 의한 항복점은 나 타나지 않고 있으며, $22 \mathrm{Co}$ 의 경우에는 $0.2 \%$ 항복점이 나 타난다. 이 연구에서는 $0.2 \%$ offset을 통한 항복강도 대신 인장 파괴강도를 강도값으로 표기하였으며, 표 3에 탄성계 수, 변형률과 같이 나타내었다. 초경합금의 인장 파괴강도

Table 3. Uni-axial tensile strength values of WC-Co alloys.

\begin{tabular}{cccc}
\hline alloys & fracture strength(MPa) & Young’s modulus(GPa) & strain \\
\hline WC-12Co & $2267.8 \pm 143.4$ & $548.7 \pm 4.7$ & $0.0046 \pm 0.0003$ \\
WC-20Co & $1865.8 \pm 230.5$ & $463.3 \pm 3.1$ & $0.0058 \pm 0.0010$ \\
WC-22Co & $1732.2 \pm 38.9$ & $362.8 \pm 3.1$ & $0.0090 \pm 0.0007$ \\
\hline
\end{tabular}




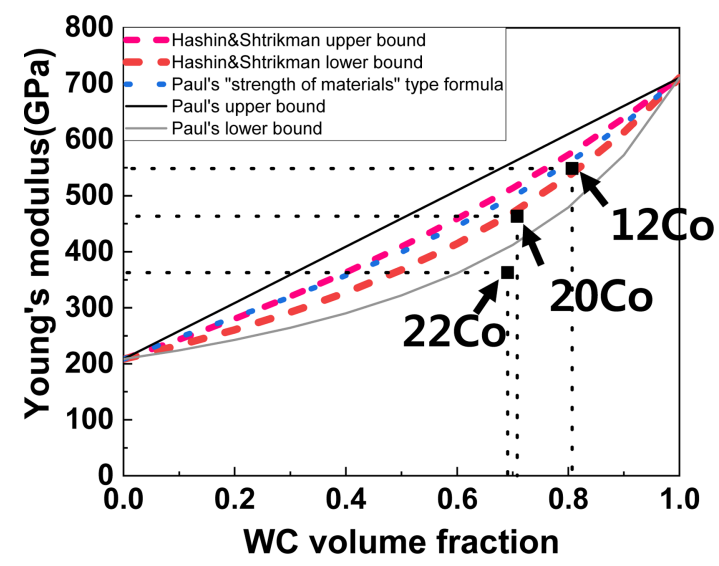

Fig. 7. Various theoretical curves on Young's modulus for WC-Co alloys plotted against volume fraction of WC.

평균은 $12 \mathrm{Co}$ 의 경우 $2267 \mathrm{MPa}, 20 \mathrm{Co}$ 의 경우 $1865 \mathrm{MPa}$, $22 \mathrm{Co}$ 의 경우 $1732 \mathrm{MPa}$ 이다. 표준편차의 경우 $20 \mathrm{Co}$ 에서 230.5 로 가장 크게 나타났고, $12 \mathrm{Co}$ 와 $20 \mathrm{Co}$ 의 표준편차는 파괴강도의 $10 \%$ 이내로 작게 나타났다. $\mathrm{WC}$ 입자 크기가 비슷한 $20 \mathrm{Co}$ 와 $22 \mathrm{Co}$ 를 보았을 때, $\mathrm{Co}$ 의 무게 분율이 $20 \%$ 를 기준으로 최대가 되고, 그 이상 $\mathrm{Co}$ 함량이 증가하면 굽힘 강도가 감소한다는 연구 결과가 있으나, 거의 동일한 미세조직적 특성을 나타낸 두 합금에서 나타난 강도값 차 이는 설명하기 어렵다. $22 \mathrm{Co}$ 초경합금의 경우 낮은 강도 값과 큰 변형률을 나타내며, 이는 Co 상이 변형성이 높은 $\mathrm{FCC}$ 상으로 존재하기 때문인 것으로 판단된다 [15]. 12Co 의 경우는 $\mathrm{WC}$ 입자 크기가 $20 \mathrm{Co}$ 와 $22 \mathrm{Co}$ 와 비교하여 매 우 작기 때문에 높은 인장 파괴강도 값을 나타낸 것이다.

반면 응력-변형률 선도에서 기울기를 나타내는 탄성계수 를 비교해보면 3종 합금 모두 탄성계수값의 표준편차는 매 우 작게 나타났다. 복합재료의 탄성계수의 경우 기지상과 강화재의 계면 강도에 의존성이 높으며, 이에 따라서 파단 전까지 모두 동일한 탄성계수값을 나타낸 것으로 판단된다. 즉, 인장 파괴강도 및 변형률 차이처럼 결함 유무 등에 의 한 영향은 적게 받은 것이다.

그림 7은 복합재료의 탄성계수 범위를 예측하는 이론적 상한과 하한선도에 $12 \mathrm{Co}, 20 \mathrm{Co}, 22 \mathrm{Co}$ 초경합금의 인장시 험에서 얻은 탄성계수값을 $\mathrm{Co}$ 부피분율에 따라 비교하여 나 타낸 그림이다. 인용한 $\mathrm{WC}$ 와 $\mathrm{Co}$ 의 인장 탄성계수는 각각 $708 \mathrm{GPa}$ 과 $206 \mathrm{GPa}$ 이다 [19]. 복합재료의 경우 계면에 대 한 하중 방향에 따라 혼합법칙의 상한값과 하한값의 범위 가 설정되고, 기지재와 강화재의 부피 분율에만 의존하게 된다. WC-Co 초경합금의 경우에서처럼 기지재와 강화재 의 탄성계수의 차이가 큰 경우에도 예측된 상한값과 하한

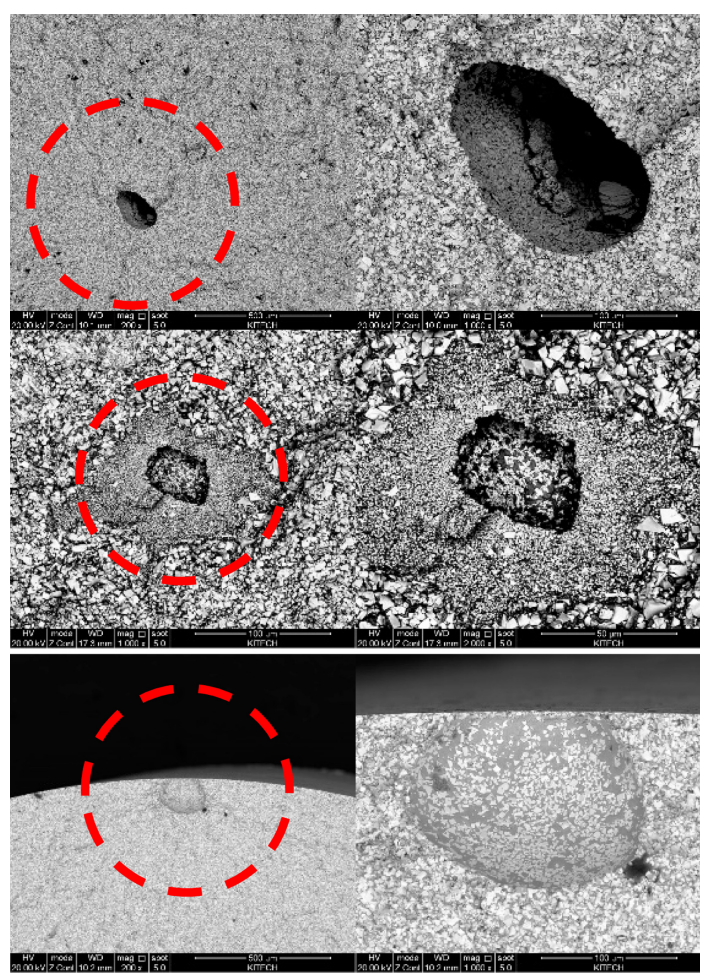

Fig. 8. Fractured surfaces of WC-20Co alloy.

값의 범위내에 존재하는 가에 검토가 필요하다. 이전의 연 구에서 Paul 등은 에너지 계산에 의해 넓은 범위의 거친 모델값을 제시하였으나, Hashin \& Shtrikman 등은 등방성 의 제 2 상(Inclusion)을 상정하여 좀 더 좁은 모델식을 제안 하였다 $[19,20]$. Paul은 기지내에 제2상이 입방정 모양으로 배열한 경우에 복합재의 해석적 인장 탄성계수 근사식 (Paul's "Strength of materials" formula)을 제안하였으며 [20], 이를 그림 7에 같이 나타내었다. $12 \mathrm{Co}$ 와 $20 \mathrm{Co}$ 의 탄 성 계수값은 Hashin \& Shtrikman 범위 안에 존재하지만, $22 \mathrm{Co}$ 의 경우 탄성 계수가 범위 밖에 존재하고 있다. $\mathrm{Co}$ 의 경우 결정구조인 $\mathrm{FCC}$ 와 $\mathrm{HCP}$ 상에 따라 탄성계수의 차이 가 있다고 알려져 있으며, $\mathrm{FCC}$ 상으로의 천이에 의해 탄성 계수가 감소한다는 보고가 있다 [21]. 즉, $22 \mathrm{Co}$ 의 경우 상 분석 결과 $\mathrm{FCC} \mathrm{Co}$ 상만 관찰되었으며, 낮은 탄성계수값을 가지는 FCC_Co 기지상이 WC-Co 초경 합금의 복합재 탄 성계수값 예측 범위에서 벗어나게 한 것으로 판단된다.

그림 8 은 $20 \mathrm{Co}$ 인장 시험편의 파단면을 주사전자현미경 으로 관찰한 사진이다. 인장강도 편차가 큰 $20 \mathrm{Co}$ 에서는 그 림 8 과 같은 다수의 기공(voids)들이 시편에서 각각 관찰 되었으며, 기공 주변에서는 $\mathrm{Co}$ 상만 존재하는 $\mathrm{Co}$ 편석 영 역이 관찰되었다. 이러한 $\mathrm{Co}$ 편석은 $\mathrm{WC}-\mathrm{Co}$ 초경합금의 
소결 과정에서 나타나는 것으로, 액상 $\mathrm{Co}$ 가 $\mathrm{WC}$ 사이의 채널을 통하여 고상 $\mathrm{WC}$ 입자 동반 없이 액상 $\mathrm{Co}$ 만으로 공극을 채우게 되어 Co lake라는 결함으로 나타난다 [22,23]. 파단 기점에서 발견된 기공들과 $\mathrm{Co}$ 편석이 인장 강도의 편차를 일으킨 것으로 판단되며 소결 조건과 미세 구조의 관계에 대해 추가적인 연구가 필요할 것으로 보여 진다 [24].

\section{4. 결 론}

WC-Co 초경합금의 미세구조가 인장 성질에 미치는 영 항을 파악하기 위하여, $\mathrm{WC}$ 입자 크기, $\lambda_{\mathrm{Co}}$, 접촉도 등의 미세구조적 인자들과 Co 결정상(phase) 분석을 진행하였다. 또한 $\mathrm{WC}-\mathrm{Co}$ 초경합금의 인장 시험편을 표준규격에 의해 제작하였고, $\mathrm{Co}$ 함량에 따른 인장 파괴강도 및 탄성계수값 을 구하였다. 본 연구를 통하여 얻은 결론은 다음과 같다.

1. WC-Co 초경합금의 미세구조적 인자값은 다음과 같 다. $12 \mathrm{Co}, 20 \mathrm{Co}, 22 \mathrm{Co}$ 각 합금의 $\mathrm{WC}$ 입자 크기는 $0.80 \pm$ $0.46 \mathrm{um}, 2.43 \pm 1.26 \mathrm{um}, 2.39 \pm 1.34 \mathrm{um}$ 이었으며, 결합제 Co상의 두께 $\lambda_{\mathrm{Co}}$ 는 $0.26 \pm 0.20 \mathrm{um}, 1.24 \pm 0.88 \mathrm{um}, 1.45 \pm$ $1.27 \mathrm{um}$ 로 $\mathrm{Co}$ 함량이 증가함에 따라 증가하는 경향을 나 타내었다. 반대로 $\mathrm{WC}-\mathrm{WC}$ 접촉도는 각각 $0.45 \pm 0.12$, $0.39 \pm 0.12,0.35 \pm 0.14$ 이었으며, $\mathrm{Co}$ 함량이 증가할수록 감 소하였다.

2. 결합제인 $\mathrm{Co}$ 상은 $\mathrm{X}$ 선 분석 결과, $12 \mathrm{Co}$ 와 $20 \mathrm{Co}$ 에 서 저온 안정상인 $\mathrm{HCP} \_\mathrm{Co}$ 상과 고온 안정상인 $\mathrm{FCC}$ Co앙 이 혼합되어 나타났다. 이는 소결 과정에서 생성된 $\mathrm{FCC}$ $\mathrm{Co}$ 가 냉각시에 $\mathrm{HCP} \mathrm{Co}$ 로 완전한 변태를 하지 못하여 나 타난 결과이며, $22 \mathrm{Co}$ 의 경우 $\mathrm{FCC} C \mathrm{Co}$ 상만 나타난 것은 냉각 과정에서 $\mathrm{Co}$ 의 상변태가 일어나지 않은 것을 알 수 있다.

3. WC-Co 초경합금의 1축 인장시험 결과 $\mathrm{Co}$ 함량 증 가에 따라서 즉, $12 \mathrm{Co}, 20 \mathrm{Co}, 22 \mathrm{Co}$ 합금의 인장 파괴강도 값은 $2267.8 \pm 143.4 \mathrm{MPa}, 1865.8 \pm 230.5 \mathrm{MPa}, 1732.2 \pm$ $38.9 \mathrm{MPa}$ 이었으며, 탄성 계수는 $548.7 \pm 4.7 \mathrm{GPa}, 463.3 \pm$ $3.1 \mathrm{GPa}, 362.8 \pm 3.1 \mathrm{GPa}$ 로 나타났다. $12 \mathrm{Co}$ 와 $20 \mathrm{Co}$ 의 탄 성계수는 이전의 연구에서 제안한 WC-Co 초경합금 탄성 계수 예측 모델의 상한값과 하한값 범위 안에 나타났지만, $22 \mathrm{Co}$ 의 탄성계수는 $\mathrm{Co}$ 결정상 차이에 의해 하한값 범위 보다 낮게 나타났다.

4. 인장 시험편 파단면에서는 매우 큰 기공(void) 등이 관찰되었으며, 이와 함께 $\mathrm{Co}$ 편석 현상도 관찰되었다. 이 러한 기공, 편석 등의 제조 결함이 인장 강도값의 편차에
크게 영향을 미치는 것으로 판단된다.

\section{감사의 글}

본 연구는 산업통상자원부의 산업소재핵심기술개발-첨단 뿌리기술(과제 번호: 20003950) 사업의 지원을 받아 수행 한 연구과제입니다.

\section{REFERENCES}

1. M. Knoerr, K. Lange, and T. Altan, J. Mater. Process. Technol. 46, 57 (1994).

2. Y. Nagao, M. Knoerr, and T. Altan, J. Mater. Process. Technol. 46, 73 (1994).

3. T. J. Chung, S. Y. Ahn, and Y. K. Paek, J. Korean Ceram. Soc. 42, 171 (2005).

4. D. H. Kim, J. S. Kim, Y. W. Woo, and H. H. Lee, J. Korean Soc. Manuf. Technol. Eng. 16, 1 (2007).

5. J. A. M. Ferreira, M. A. Pina Amaral, F. V. Antunes, and J. D. M. Costa, Int. J. Refract. Met. Hard Mater. 27, 1 (2009).

6. G. E. Spriggs, Int. J. Refract. Met. Hard Mater. 13241 (1995).

7. J. Hong, J. of the Korean Inst. of Met. \& Mater. 32, 1566 (1994).

8. K.-M. Cho, T.-W. Hyun, and H.-C. Lee, J. of the Korean Inst. of Met. 23, 19 (1985).

9. D. G. F. O’Quigley, S. Luyckx, and M. N. James, J. Mater. Sci. Eng. A 209, 228 (1996).

10. S.-E. Kim, S.-H. Hong, and I.-J. Shon, Korean J. Met. Mater. 58, 453 (2020).

11. W. Weibull, A Statistical Theory of the Strength of Materials, p.18, Nr. Stockholm (1939).

12. M. J. Kerper, L. E. Mong, M. B. Stiefel, and S. F. Holley, J. Res. Nati. Bur. Stand. 61, 3 (1958).

13. I. W. Kwon, Y. H. Seo, and K. H. Jung, Trans. Mater. Process 27, 370 (2018).

14. ISO 449-2:2008, Hardmetals Metallographic Determination of Microstructure-Part 2: Measurement of WC Grain Size, International Standard Organisation, Geneva, (2008).

15. J. Gurland, Trans. AIME 5, 212 (1958).

16. H.-S. Ryoo, S.-K. Hwang, G.-H. Ha, B.-K. Kim, and H.-S. Chung, J. kor. Inst. Met. \& Mater. 361915 (1998).

17. S. Luyckx, and A. Love, Int. J. Refract. Met. Hard Mater. 24, 75 (2006).

18. T. Nishizawa and K. Ishida, The Co(Cobalt) System. Bulletin of Alloy Phase Diagrams 4, 387 (1983). 
19. Z. Hashin and S. Shtrikman, J. Mech. Phys. Solids, 11127 (1963).

20. B. Paul, Trans. TMS-AIME 218, 127 (1963).

21. J. E. Bidaux, R. Schaller, and W. Benoit, Journal de Physique Colloq. 46, C8-477-C8-482 (1987).

22. K. Sakagami, S. Kouno, and T. Yamamoto, Japan Soc.
Powder Metall. 54, 260 (2007).

23. O. Eso, Z. Fang, and A. Griffo, Int. J. Refract. Hard Met. 23, 233 (2005).

24. M. Q. Zeng, J. L. Tu, M. Zhu, W. Wang, J. W. Liu, and Z. C. Lu, Met. Mater. Int. 26, 1373 (2020). 